\title{
Penerapan Model Pembelajaran Kausalitik Untuk Meningkatkan Kemampuan Bernalar Dalam Pembelajaran Fisika Masa Learning from Home Pandemi Covid-19
}

\author{
Nurjamilah", Joni Rokhmat, Hairunnisyah Sahidu, Ahmad Harjono \\ Program Studi Pendidikan Fisika, Universitas Mataram \\ *Email: nurjamilahp.fisika@gmail.com
}

Received: 29 Juni 2020; $\quad$ Accepted: 14 November 2020; Published: 30 November 2020

DOI: http://dx.doi.org/10.29303/jpft.v6i2.1960

\begin{abstract}
The Covid-19 pandemic requires teachers to make innovations in learning, such as utilizing appropriate applications and choosing the right learning model to encourage students' reasoning abilities. This study aims to identify the effect of the causal learning model on students' reasoning abilities in learning physics during the learning from home period due to the Covid-19 pandemic. This type of research is a quasi-experimental study with a $2 \times 2$ factorial design. The population is all students of class X MIA Madrasah Aliyah Negeri 2 (MAN 2) Mataram. Sampling using purposive sampling technique so that selected students of class X-MIA 3 (31 students) as the experimental class and class $X$-MIA 4 (30 students) as the control class. The instrument used to measure reasoning ability was a description test of 4 items. The results showed that the data were normally distributed and homogeneous

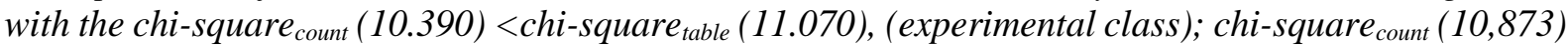
$<$ chi-square table $(11,070)$, (control class); and $F_{\text {count }}(1,502)<F_{\text {table }}(1,799)$. The hypothesis was tested using the t-test with a significance level (sig.) Of 5\%. Hypothesis test results show the sig value. smaller than 0.05 ( $\alpha<0.05)$ ( $H_{0}$ rejected) and the experimental class gain $(56.02 \%$, moderate) is higher than the gain for the control class $(38.28 \%$, low). The conclusion is that the causal learning model has an effect on improving students' reasoning ability in learning physics during the learning from home period due to the Covid-19 pandemic. Recommendations that can be given in an effort to improve students 'reasoning abilities are to present physical phenomena in the form of pictures that can stimulate students' thinking activities.
\end{abstract}

Keywords: Causalitic Learning Model; Students' Reasoning Ability; Physics Learning; Covid-19 Pandemic

\section{PENDAHULUAN}

Era revolusi industri 4.0, disebut sebagai era disrupsi yaitu suatu era terjadinya perubahan besar-besaran pada semua bidang kehidupan, tak terkecuali dalam bidang pendidikan. Salah satu contohnya adalah sistem pembelajaran di dalam kelas. Pembelajaran yang semula diselenggarakan secara langsung di kelas bukan tidak mungkin akan digantikan melalui sistem pembelajaran secara tidak langsung atau dalam jaringan (daring). Pembelajaran daring merupakan sistem belajar yang memanfaatkan teknologi internet dimana seseorang dapat belajar di mana saja, kapan saja, dan dalam situasi apa saja meskipun jarak berjauhan.

Pembelajaran daring ini kemudian menjadi tantangan tersendiri bagi guru dan siswa. Guru dituntut secara terus-menerus meningkatkan kompetensinya menjadi guru hebat yang mampu menginspirasi agar siswa mampu terlibat secara aktif dan kooperatif dalam pembelajaran untuk mengembangkan kemampuan bernalar dan berargumentasi (Kusmiarti \& Hamzah, 2019). Sementara siswa dituntut untuk memiliki beberapa kemampuan salah satunya ialah kemampuan bernalar sebagai bekal menjadi pribadi adaptif dalam menyelesaikan soal maupun 
menghadapi permasalahan di kehidupan sehari-hari (Supeno et al. 2017).

Disisi lain tantangan yang saat ini juga dihadapi guru dan siswa adalah melakukan kegiatan pembelajaran di tengah pandemi Covid-19. Pandemi Covid-19 merupakan wabah peyakit yang terjadi di Indonesia dan seluruh dunia yang diakibatkan oleh SARSCOV2 (Napsawati, 2020). Dampak pandemi Covid-19 terhadap pembelajaran yaitu pembelajaran harus dilakukan dari rumah atau learning from home (LFH).

LFH didefinisikan sebagai kegiatan menjalankan proses pembelajaran dari rumah sebagai upaya menggantikan proses tatap muka di kelas secara langsung. LFH merupakan kebijakan pemerintah yang mengharuskan lembaga pendidikan terkait memberikan alternatif dan inovasi proses pendidikan bagi peserta didik yang tidak bisa melaksanakan proses pendidikan langsung di lembaga pendidikan (Purwanto et al. 2020). Kondisi ini kemudian menuntut guru untuk memperbarui informasi dalam memilih model atau metode pembelajaran yang digunakan, dengan harapan pembelajaran tetap dapat terlaksana dan kualitas pembelajaran dapat menjadi lebih baik.

Hasil observasi yang telah dilakukan di MAN 2 Mataram menunjukkan proses pembelajaran khususnya pembelajaran fisika yang berlangsung saat ini hanya berisi penjelasan materi dan penugasan berupa latihan soal yang kurang mengaktifkan siswa. Kurang aktifnya siswa dalam pembelajaran fisika mengakibatkan kemampuan bernalar siswa tidak terlatih yang berimbas pada kemampuan bernalar yang tidak berkembang. Dapat dikatakan bahwa kemampuan bernalar menjadi aspek penting yang perlu dikembangkan dalam pembelajaran fisika. Lawson et al. (2007) menegaskan bahwa salah satu faktor penting yang mempengaruhi hasil belajar adalah kemampuan bernalar.

Kemampuan bernalar adalah usaha untuk menggambarkan sesuatu guna menyelesaikan permasalahan melalui aktifitas berpikir. Adanya kemampuan bernalar yang terus dilatih akan meningkatkan daya berpikir dan pengetahuan siswa serta memudahkan dalam menyelesaikan permasalahan fisika sehingga dapat meningkatkan hasil belajar siswa. Nohda (2000), mengungkapkan bahwa agar kemampuan penalaran siswa dapat berkembang secara optimal, siswa harus memiliki kesempatan yang sangat terbuka untuk berpikir dan beraktivitas dalam memecahkan berbagai permasalahan. Dengan demikian, model pembelajaran yang dapat memberikan otonomi seluas-luasnya kepada siswa dalam berpikir untuk menyelesaikan permasalahan dapat menumbuh-kembangkan kemampuan siswa dalam penalaran dan berpikir strategis secara optimal (Herman, 2007).

Salah satu model pembelajaran yang menyajikan pembelajaran dengan karakteristik berpikir dalam menyelesaikan permasalahan yaitu model pembelajaran kausalitik. Model pembelajaran kausalitik adalah model pembelajaran yang dikembangkan dan dirancang berdasarkan pada pendekatan berpikir kausalitik dan analitik. Melalui aktivitas berpikir kausalitik, siswa diarahkan mampu menganalisis setiap fenomena fisika. Sedangkan dari aktivitas berpikir analitik, siswa diarahkan mampu menyusun rasionalisasi dalam bentuk argumen untuk menjelaskan bagaimana kondisi setiap unsur penyebab sehingga secara bersama-sama menghasilkan suatu akibat dari fenomena fisika (Rokhmat et al., 2020). Model pembelajaran kausalitik terdiri dari 4 fase pembelajaran yaitu: (1) Fase orientasi (2) Fase eksplorasi dan pengembangan konsep 
kausalitas (3) Fase penyusunan argumen (4) Fase evaluasi (ibid).

Penerapan model pembelajaran kausalitik yang diharapkan dapat meningkatkan kemampuan bernalar siswa juga didasarkan pada beberapa penelitian yang telah dilakukan, oleh Anshori, Rokhmat, \& Gunada (2019) yang menyatakan bahwa model pembelajaran kausalitik membiasakan siswa berpikir secara divergen dalam menyelesaikan permasalahan. Selanjutnya Tamami et al. (2017) dan Rokhmat et al. (2017a, 2017b, 2017c), mengungkapkan bahwa pendekatan berpikir kausalitik ber-scaffolding berpengaruh dalam meningkatkan kemampuan pemecahan masalah siswa. Pendekatan ini juga memfasilitasi berkembangnya kemampuan dalam berpikir kausalitik (Rokhmat et al. 2019). Selanjutnya Rokhmat et al. (2019), juga mengutarakan pendekatan berpikir kausalitik efektif dalam meningkatkan kemampuan memahami masalah, memilih penyebab dan akibat, membedakan penyebab mana sebagai faktor masingmasing akibat, menentukan dan menerapkan konsep, prinsip, teori, dan/atau hukum fisika tersebut saat menyusun argumen.

Uraian permasalahan tersebut mendorong peneliti untuk melakukan suatu penelitian terkait pengaruh model pembelajaran kausalitik terhadap kemampuan bernalar siswa dengan tujuan untuk mengidentifikasi pengaruh model pembelajaran kausalitik terhadap kemampuan bernalar siswa dalam pembelajaran fisika pada masa learning from home akibat pandemi Covid-19 di MAN 2 Mataram.

\section{METODE PENELITIAN}

Jenis penelitian yang dilakukan adalah kuasi eksperimen dengan desain penelitian yang diterapkan dalam penelitian ini adalah factorial $2 \times 2$.

\begin{tabular}{cccc}
\hline Kelas & $\begin{array}{c}\text { Tes } \\
\text { Awal }\end{array}$ & Perlakuan & $\begin{array}{c}\text { Tes } \\
\text { Akhir }\end{array}$ \\
\hline Eksperimen & $\mathrm{O}_{11}$ & $\mathrm{X}_{1}$ & $\mathrm{O}_{12}$ \\
Kontrol & $-\mathrm{O}_{21}^{-}$ & $\mathrm{X}_{2}^{-}$ & $\mathrm{O}_{22}^{--}$ \\
\hline \multicolumn{3}{c}{ Diadaptasi dari Setyosari, $(2016)$}
\end{tabular}

Populasi penelitian ini adalah seluruh siswa kelas X MIA MAN 2 Mataram dengan teknik pengambilan sampel menggunakan purposive sampling, sehingga diperoleh siswa kelas X MIA 3 yang berjumlah 31 siswa sebagai kelas eksperimen dan siswa kelas X MIA 4 yang berjumlah 30 siswa sebagai kelas kontrol.

Teknik pengumpulan data berupa tes tertulis berbentuk soal uarain yang terdiri dari 4 item soal kemampuan bernalar. Nilai kemampuan bernalar diambil dari masingmasing skor indikator kemampuan bernalar. Nilai yang dimaksud diambil dari nilai post test dengan teknik penilaian menggunakan akumulasi dari skor kemampuan kemampuan bernalar pada setiap indikator.

Indikator kemampuan bernalar (IKB) yang digunakan dalam penelitian ini dikaitkan dengan karakteristik pemecahan masalah dalam pembelajaran kausalitik. IKB yang dimaksud adalah Mengurutkan (ordering), yaitu kemampuan mengurutkan kondisi yang menjadi penyebab (IKB-1); Memprediksi (predicting), yaitu kemampuan memprediksi berbagai kemungkinan akibat yang dapat terjadi (IKB-2); Menganalisis (analayzing), yaitu kemampuan menganalisis penyebab yang merupakan faktor dari setiap akibat terprediksi (IKB-3); Mengontrol (controlling), yaitu kemampuan mengontrol dengan cara menentukan mana konsep, prinsip, teori, dan/atau hukum fisika yang dapat digunakan untuk mendukung dalam mengidentifikasi beberapa penyebab (IKB4); dan Menerapkan (applying), yaitu 
kemampuan menerapkan konsep, prinsip, teori, dan/atau hukum fisika yang direpresentasikan dalam berntuk argumen terjadinya setiap akibat terprediksi (IKB-5).

Instrumen tes kemampuan bernalar sebelum digunakan dalam penelitian ini harus memenuhi beberapa syarat yaitu uji validitas, reliabilitas, tingkat kesukaran, dan daya beda soal. Uji hipotesis yang digunakan dalam penelitian ini menggunakan uji-t dengan taraf signifikan 5\% dan uji N-gain untuk mengetahui peningkatan kemampuan bernalar fisika siswa pada kelas eksperimen maupun kelas kontrol.

\section{HASIL DAN PEMBAHASAN}

Penelitian ini bertujuan untuk mengidentifikasi pengaruh model pembelajaran kausalitik terhadap kemampuan bernalar siswa dalam pembelajaran fisika pada masa learning from home akibat pandemi Covid-19. Penelitian dilakukan di MAN 2 Mataram dengan pemberian perlakuan model pembelajaran kausalitik pada kelas eksperimen dan model pembelajaran langsung pada kelas kontrol. Kegiatan penelitian ini dilakukan dalam jaringan (daring) menggunakan aplikasi ZOOM Cloaud Meeting (ZOOM).

ZOOM merupakan salah satu aplikasi yang memungkinkan peneliti dapat melakukan pembelajaran tatap muka seperti di kelas dan berinteraksi secara komunikatif karena ZOOM menyediakan fasilitasfasilatas yang dapat menunjang proses pembelajaran layaknya belajar di dalam kelas. Fasiliats yang dimaksud dianataranya,
Breakout Rooms untuk diskusi kelompok, Share Screen untuk menampilkan bahan ajar (video dan power point), Whiteboard untuk menjelaskan materi, Chat untuk berkirim pesan, dan Record untuk merekam kegiatan yang dilakukan selama pembelajaran berlangsung, dengan ZOOM kegiatan belajar mengajar lebih efektif seperti kegiatan mengajar tatap muka di kelas (Suminiangsih, 2020). Skenario atau rencana pelaksanaan pembelajaran (RPP) yang dilaksanakan sebenarnya sama seperti pembelajaran di kelas, perbedaannya yaitu peneliti dan siswa tidak dapat bertemu tatap muka secara langsung melainkan bertemu di layar Handphone ( $\mathrm{Hp})$ atau Laptop.

Hasil penelitian dianalisis berdasarkan pretest dan posttest pada kedua kelas sampel. Hasil pretest menunjukan bahwa tingkat kemampuan bernalar siswa di kedua kelas sebelum diberikan perlakuan, masih sangat rendah. Hal ini dapat dilihat dari nilai rata-rata pretest kemampuan siswa pada kedua kelas. Tabel 1 memperlihatkan nilai rata-rata pretets kemampuan bernalar untuk kelas eksperimen yaitu 33 dan untuk kelas kontrol adalah 23.

Rendahnya nilai rata-rata pretest pada Tabel 1 mengindikasikan bahwa pembelajaran yang berlangsung selama ini belum mampu meningkatkan kemampuan bernalar siswa karena aspek kognitif hanya ditekankan pada hasil bukan pada aspek proses yang melibatkan kemampuan bernalar. Selain itu, penyebab lainnya karena kedua kelompok sampel belum memperoleh materi momentum dan impuls yang sesuai dengan jenjangnya.

Tabel 1. Hasil Uji Homogenitas dan Normalitas Kemampuan Bernalar

\begin{tabular}{cccccc}
\hline Kelas & Jumlah Siswa & Rata-rata & $\boldsymbol{F}_{\text {hitung }}$ & $\boldsymbol{F}_{\text {tabel }}$ & Keterangan \\
\hline Eksperimen & 31 & 33 & 1,569 & 1,850 & Homogen \\
Kontrol & 30 & 23 & & & \\
Kelas & Jumlah Siswa & Rata-rata & $\boldsymbol{\chi}^{\mathbf{2}}{ }_{\text {hitung }}$ & $\boldsymbol{\chi}_{\text {tabel }}$ & Keterangan \\
Eksperimen & 31 & 70,806 & 10,390 & 11,700 & Terdistribusi \\
Kontrol & 30 & 52,167 & 10,873 & & Normal \\
\hline
\end{tabular}


Data hasil pretest kemampuan bernalar kedua kelas dianalisis untuk mengetahui homogenitas data. Tabel 1 menunjukan bahwa data hasil pretest kemampuan bernalar kelas eksperimen dan kelas kontrol homogen. Berdasarkan uji homogenitas dapat disimpulkan bahwa kemampuan bernalar siswa setara sebelum diberikan perlakuan. Hal ini sesuai dengan pendapat Setiawan \& Harta (2014) uji homogenitas berfungsi untuk mengetahui kesetaraan kemampuan awal kedua kelas.

Untuk mengukur pengaruh peningkatan kemampuan bernalar siswa setelah diberi perlakuan model pembelelajaran kausalitik dilakukan posttest dengan materi dan bobot soal yang sama seperti yang diberikan pada saat pretest. Hasil posttest kemampuan bernalar siswa menunjukan nilai rata-rata kelas eksperimen yaitu 70,806 lebih tinggi dari nilai rata-rata kelas kontrol yaitu 52,167. Data posttest kemampuan bernalar kelas eksperimen dan kelas kontrol diuji normalitasnya sebagai bagian tahapan uji hipotesis. Hasil uji normalitas tersebut dapat dilihat pada Tabel 1.

Tabel 1 juga memperlihatkan bahwa data hasil posttest kemampuan bernalar kelas eksperimen dan kelas kontrol terdistribusi normal yang ditentukan dari nilai chi kuadrat data kedua kelas. Berdasarkan uji normalitas dapat disimpulkan bahwa jenis statistik yang digunakan sebagai tahapan uji hipotesis adalah uji statistik parametrik. Hal ini sesuai dengan pendapat Sundayana (2016), yang menyatakan normalitas sebaran data menjadi syarat untuk menentukan jenis statistik apa yang digunakan dalam analisis selanjutnya. Uji statistik parametrik yang digunakan adalah uji-t dengan taraf signifikansi 0,05. Uji-t adalah suatu tes statistik yang memungkinkan untuk membandingkan dua skor rata-rata yang diperoleh dari perbedaan nyata dua kelompok (Setyosari, 2016).

Nilai signifikansi statistik uji-t yang diperoleh sebesar 0,005. Nilai signifikansi ini lebih kecil dari taraf signifikansi 0,05 atau $(0,005<0,05)$ sehingga hipotesis $H_{0}$ ditolak. Artinya terdapat perbedaan yang signifikan antara kemampuan bernalar siswa dalam pembelajaran fisika pada kelas eksperimen dan kelas kontrol. Hasil ini menunjukkan bahwa model pembelajaran kausalitik berpengaruh dalam meningkatkan kemampuan bernalar siswa dalam pembelajaran fisika di MAN 2 Mataram.

Peningkatan kemampuan bernalar siswa setelah diberikan perlakuan model pembelajaran kausalitik dapat disebabkan karena tahapan pembelajaran model kausalitik yang melatih dan membimbing siswa untuk mempunyai dan menggunakan nalar secara aktif pada saat pembelajaran berlangsung. Siswa dibimbing dalam mengurutkan, memprediksi, menganalisis, mengontrol, hingga menerapkan konsep, prinsip, teori, dan/atau hukum ke dalam fenomen-fenomena fisika dalam kehidupan sehari-hari.

Keterlibatan siswa berpikir secara aktif dalam pembelajaran akan merangsang kemampuan bernalarnya. Sebagaimana penelitian yang telah dilakukan oleh Burais et al. (2016) yang mengutarakan bahwa salah satu penyebab rendahnya kemampuan penalaran matematis siswa adalah proses pembelajaran yang dilakukan oleh guru di kelas kurang melibatkan siswa secara aktif dalam proses pembelajaran, sehingga untuk meningkatkan kemampuan penalarannya maka siswa harus dilibatkan secara aktif.

Peningkatan kemampuan bernalar siswa lebih lanjut dapat dilihat dari hasil skor rata-rata uji $\mathrm{N}$-gain pada kedua kelas sampel. Gambar 1 memperlihatkan persen 
rata-rata $\mathrm{N}$-gain untuk kelas eskperimen sebesar $56,02 \%$ dan termasuk dalam kategori sedang. Sedangkan persen rata-rata $\mathrm{N}$-gain kelas kontrol sebesar 38,28\% dan termasuk dalam kategori rendah. Hasil tersebut mengindikasikan bahwa penerapan model pembelajaran kausalitik cukup berpengaruh untuk meningkatkan kemampuan bernalar siswa dalam pembelajaran fisika di MAN 2 Mataram pada materi momentum dan impuls.

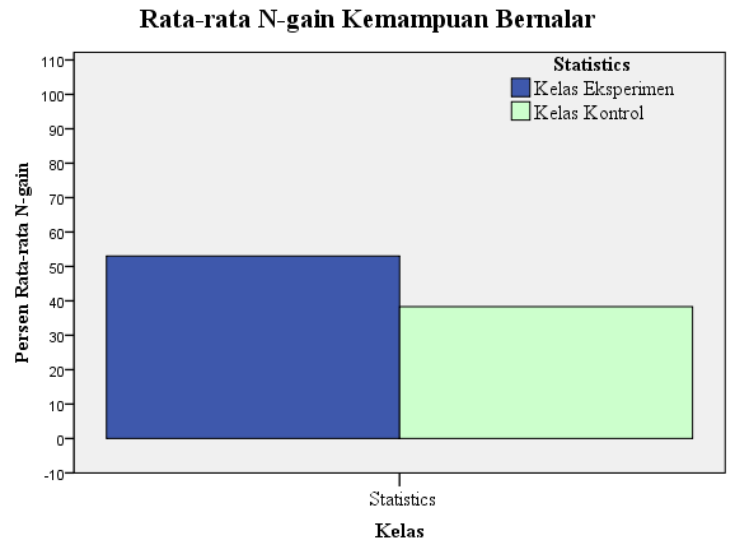

Gambar 1. Rata-rata $N$-gain Kemampuan Bernalar

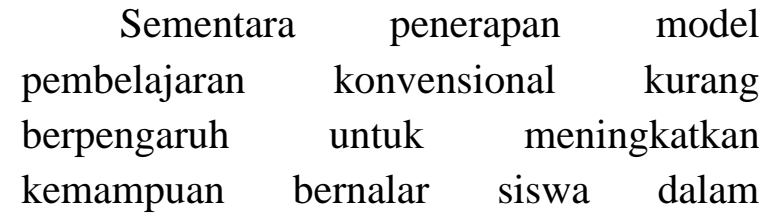
pembelajaran fisika di MAN 2 Mataram pada materi tersebut. Perbedaan hasil peningkatan pada kedua kelas dikarenakan penerapan model pembelajaran kausalitik melatih kemampuan bernalar siswa pada setiap tahapan pembelajarannya.

Tahap pertama yaitu orientasi, pada tahap ini peneliti memberikan demonstrasi fenomena-fenomena fisika dalam kehidupan sehari-hari berupa video dalam bentuk power point, seperti anak yang memilih antara menghentikan mobil atau sepeda dan memberikan pertanyaan seperti "Manakah yang lebih sukar untuk dihentikan (a) Mobil; (b) Sepeda". "Mengapa hal tersebut dapat terjadi?", kemudian memperoleh respon dari siswa berupa jawaban yang bervariatif.

Kegiatan demonstrasi dan memberikan pertanyaan kepada siswa ini merupakan langkah awal dalam melatih kemampuan bernalar siswa, karena siswa akan memikirkan jawaban atas pertanyaan yang diajukan. Sebagaimana penelitian yang telah dilakukan Siregar (2019) menegaskan pertanyaan yang mengharuskan siswa untuk mengkomunikasikan gagasannya dapat mengasah kemampuan bernalar siswa. Indikator kemampuan bernalar yang dapat dilatihkan pada fase orientasi adalah mengurutkan (ordering). Pada tahap orientasi siswa diberikan sebuah pertanyaan terkait materi momentum dan impuls yang menuntut siswa untuk memahami maksud pertanyaan dengan mengurutkan kondisi yang mejadi penyebab hubungan antara momentum dan impuls. Dalam tahap awal ini telah melatihkan kemampuan bernalar siswa dalam menjawab pertanyaan dari peneliti.

Tahap kedua yaitu eksplorasi dan pengembangan konsep kausalitas, dalam tahap ini siswa dituntun lebih aktif untuk menggali, menyelidiki dan menganalisis berbagai penyebab yang mungkin menghasilkan suatu akibat dari fenomena yang disediakan dalam bentuk LKS. Pada tahap eksplorasi siswa diberikan LKS yang telah dibuat untuk setiap pertemuan agar melatih indikator-indikator kemampuan bernalar. Indikator yang dilatih pada tahap ini yaitu mengurutkan (ordering), memprediksi (predicting), dan menganalisis (analayzing). Adapun peran peneliti hanya memberi bimbingan dengan cara menunjukkan sebagian contoh (bantuan tahapan atau scaffolding) dari proses penyelesaian fenomena dalam LKS. Scaffolding sangat mendukung penerapan model pembelajaran kausalitik dan membantu siswa karena siswa belum 
terbiasa dengan soal yang berbentuk kausalitik. Dengan scaffolding, siswa mampu menyelesaikan masalah melebihi kemampuan mereka (Rokhmat et al., 2019).

Berdasarkan nilai rata-rata yang diperoleh pada posttest, mengurutkan (ordering) dan memprediksi (predicting) merupakan indikator dengan nilai rata-rata tertinggi. Hal ini dapat terjadi karena siswa dilatihkan agar dapat mengurutkan kondisi yang menjadi penyebab pada materi momentum dan impuls. Setelah mereka mampu mengurutkan maka mereka dapat memprediksi berbagai kemungkinan akibat yang dapat terjadi berdasarkan fenomena yang ada pada setiap LKS yang diberikan. Buaris et al. (2016) juga mengungkapkan hal yang sama dalam penelitiannya pada saat siswa memperediksi jawaban atau solusi akan membantu siswa melakukan penalaran analogi yaitu penarikan kesimpulan berdasarkan keserupaan data atau proses.

Tahap ketiga adalah menyusun argumen, pada tahap ini siswa menyusun argumen mengapa setiap akibat tersebut bisa terjadi dikaitkan dengan setiap kombinasi yang menjadi penyebab dengan menyertakan konsep, prinsip, teori atau hukum fisika yang terkait dengan fenomena momentum dan impuls. Sebelum menyusun argumen siswa dibiasakan untuk selalu bernalar dalam mengidentifikasi kemungkinan dari setiap unsur penyebab sampai akhirnya menentukan akibat yang mungkin terjadi dengan menerapkan konsep, prinsip, teori, atau hukum-hukum yang terkait untuk menjelaskan mengapa setiap akibat tersebut dapat terjadi dengan bahasa, kata-kata, dan pemikiran siswa sendiri serta memberikan uraian terkait penjelasannya.

Tahap ini melatihkan kemampuan bernalar siswa yaitu mengontrol (controlling) dan menerapkan (applying), karena pada tahap ini siswa dilatih untuk menentukan konsep, prinsip, teori atau hukum fisika yang dapat digunakan untuk mendukung dalam mengidentifikasi beberapa penyebab yang menghasilkan suatu akibat, kemudian menerapkan konsep, prinsip, teori atau hukum fisika mana yang diperlukan dalam mengidentifikasi penyebab-penyebab sehingga menghasilkan suatu akibat tertentu dalam fenomena momentum dan impuls yang telah mereka pahami melalui LKS yang telah dikerjakan bersama kelompok.

Tahap keempat yaitu evaluasi, pada tahap ini yang dilakukan siswa adalah menyamakan persepsi dan merevisi persepsi yang keliru terhadap materi momentum dan impuls. Kemampuan bernalar yang dapat dilatihkan pada tahap ini yaitu menerapkan (applying) konsep, prinsip, teori dan/atau hukum fisika mana yang diperlukan sehingga siswa menyusun argumen dalam membuat keputusan akhir atau kesimpulan. Pada tahap ini, peneliti memfasilitasi setiap kelompok untuk menyamakan persepsi dengan cara mengemukakan kesimpulan dari pembelajaran yang telah dilakukan yaitu tentang materi momentum dan impuls. Peneliti juga memberikan penguatan atas pendapat yang dikemukan oleh semua kelompok dengan mengembangkan pertanyaan lanjutan yang bersifat konstruktif.

Berdasarkan rangkaian pembelajaran yang diterapkan pada kelas eksperimen menunjukkan adanya proses untuk melatih kemampuan bernalar karena kemampuan bernalar tidak akan berkembang apabila tidak dilatih dan dibiasakan. Seperti yang dinyatakan oleh Agustin (2016), kemampuan bernalar dapat ditingkatkan dengan melatih dan membiasakan menyajikan pelajaran dengan mendorong siswa untuk mencari atau memecahkan suatu masalah atau persoalan. Kemampuan bernalar yang tinggi dibutuhkan tidak hanya dalam membuat keputusan dan 
menyelesaikan masalah, kemampuan bernalar yang tinggi akan berimbas pada kemampuan siswa dalam menyelesaikan masalah (Ding, Reay, Lee, \& Bao, 2011).

Indikator-indikator kemampuan

bernalar yang harus dicapai siswa lebih banyak dilatihkan dalam penerapan model pembelajaran kausalitik dibandingkan dengan model pembelajaran langsung. Terlihat dari nilai rata-rata kemampuan bernalar pada kelas eksperimen lebih tinggi daripada kelas kontrol. Nilai rata-rata posttest kelas eksperimen 70,806 sedangkan kelas kontrol sebesar 52,167. Berdasarkan data yang telah didapatkan terlihat bahwa peningkatan nilai rata-rata yang tinggi dan signifikan secara statistik terjadi pada kelas eksperimen. Hal ini dapat terjadi karena model pembelajaran kausalitik memfasilitasi siswa untuk berpikir secara kausal dan analitik yang dibutuhkan dalam mendorong kemampuan bernalar seseorang.

Berpikir kausalitik dan analitik ini memiliki kelebihan, sebagaimana yang diungkapkan Rokhmat (2013b), diantaranya: 1) siswa akan terlatih untuk menganalisis fenomena fisika, 2) memahami konsep secara menyeluruh, 3) berpikir secara kritis dan sintesis, 4) berpikir secara divergen, dan 5) menjawab permasalahan berdasarkan konsep fisika. Kelebihan tersebut kemudian memicu berkembangnya setiap indikator kemampuan bernalar yang diukur. Hasil penelitian yang didapatkan oleh peneliti sejalan dengan penelitian yang dilakukan oleh Wulandari (2019), menyatakan bahwa penerapan model pembelajaran kausalitik dengan tepat dapat meningkatkan kemampuan pemecahan masalah siswa secara signifikan. Hal yang sama juga diungkapkan oleh Rokhmat et al. (2017b), pendekatan berpikir kausalitik efektif digunakan dalam pembelajaran fisika yang ditunjukkan dengan peningkatan kemampuan pemecahan masalah.
Terdapat beberapa faktor yang menyebabkan pelaksanaan penelitian ini menjadi kurang maksimal. Faktor pertama adalah kegiatan penelitian ini dilakukan dalam jaringan (daring). Faktor kedua yaitu kurangnya pengalaman siswa dalam menyelesaikan soal yang menekankan proses berpikir. Faktor ketiga yaitu sulitnya siswa memahami gamabar ilustrasi yang diberikan sehingga menyulitkan siswa dalam memberikan argumen untuk menjelaskan fenomena yang ada.

Strategi yang dapat digunakan untuk mengatasi masalah tersebut adalah menggunkan aplikasi yang tidak terlalu menghabiskan banyak kuota, namun memiliki fasilitas yang mendukung kegiatan pembelajaran. Utamanya aplikasi yang memiliki fasilitas Share Screen dan Whiteboard untuk penelitian yang terdapat kelas ekperimen dan kelas kontrol. Fasilitas Share Screen sangat membantu pada saat pengambilan data, melalui fasilitas ini peneliti dapat membagikan prangkat tes yang telah disiapkan dan memantau kegiatan siswa tanpa harus takut siswa bekerja sama dengan temannya. Komunikasi antara semua pihak yang terlibat sangat menunjang keberhasilan dari penilitian daring ini.

\section{PENUTUP}

Berdasarkan hasil penelitian dan pembahasan, maka dapat diambil kesimpulan bahwa terdapat pengaruh model pembelajaran kausalitik terhadap kemampuan bernalar siswa dalam pembelajaran fisika di MAN 2 Mataram pada masa learning from home akibat pandemi Covid-19. Pengaruh yang dimaksud adalah terjadi peningkatan kemampuan bernalar dalam pembelajaran fisika pada kelas eksperimen.

Model pembelajaran kausalitik dapat diterapkan untuk meningkatkan kemampuan bernalar siswa dalam pembelajaran fisika 
dengan memperhatikan beberapa hal seperti jaringan (signal) dan keamanan aplikasi yang digunakan jika pelaksanaan penelitian dilakukan dalam jaringan (daring), alokasi waktu selama pembelajaran, fenomena yang dibahas dalam LKS serta memperhatikan bentuk pemberian bantuan (scaffolding) yang disajikan.

\section{REFERENSI}

Agustin, R. D. 2016. Kemampuan Penalaran Matematika Mahasiswa malalui Pendekatan Problem Solving. Jurnal Pedagogi, 5(2), 180-181.

Anshori, I. A., Rokhmat, J., \& Gunada, I. W. 2019. Pengaruh Model Pembelajaran Kausalitik terhadap Kemampuan Pemecahan Masalah ditinjau dari Kreativitas Peserta Didik. Jurnal Pendidikan Fisika dan Teknologi, 5(2), 210

Burais, L., Ikhsan, M., \& Duskri, M. 2016. Peningkatan Kemampuan Penalaran Matematis Siswa melalui Model Discovery Learning. Jurnal Didaktik Matematika, 3(1), 79-84.

Ding, L., Reay, N., Lee, A., \& Bao, L. 2011. Exploring the Role of Conceptual Scaffolding in Solving Synthesis Problems. Physical Review Special Topics-Physics Education Research, $7(2), 8$.

Herman, T. 2007. Pembelajaran Berbasis Masalah untuk Meningkatkan Kemampuan Penalaran Matematis Siswa SMP. Jurnal cakrawala pendidikan, 26(1), 45.

Kusmiarti, R., \& Hamzah, S. 2019. Literasi dalam Pembelajaran Bahasa Indonesia di Era Industri 4.0. Prosiding Seminar Nasional Bulan Bahasa (Semiba), 215. Diakses dari https://ejournal.unib.ac.id/index.php/s emiba

Lawson, A. E., Banks, D. L., \& Logvin, M. 2007. Self-Efficacy, Reasoning Ability, And Achievement In College
Biology. Journal of Research in Science Teaching, 44 (5), 706-724.

Napsawati. 2020. Analisis Situasi Pembelajaran IPA Fisika Dengan Metode Daring Di Tengah Wabah Covid-19. Jurnal Pendidikan Fisika dan Terapannya, 3(1), 7.

Nohda, N. 2000. Learning and Teaching Through Open-ended Approacrh Method. Dalam Tadao Nakahara dan Masataka Koyama (editor) Proceeding of the 24th of the Intenational Group for the Psychology of Mathematics Education. Hiroshima: Hiroshima University.

Purwanto, A., Pramono, R., Asbari, M., Santoso, P. B., Wijayanti, L. M., Yun, C. C \& Putri, R. S. 2020. Studi Eksploratif Dampak Pandemi COVID-19 Terhadap Proses Pembelajaran Online Di Sekolah Dasar. Journal of Education, Psychology, and Counseling, 2 (1), 23.

Rokhmat, J. 2013. Peningkatan Kemampuan Pemecahan Masalah Mahasiswa Calon Guru Fisika melalui Berpikir Kausalitas dan Analitik [The Increase of Problem-solving Ability of Physics Pre-service Student through Causality and Analytic Thinking]. Disertasi Doktor pada Pendidikan IPA. Universitas Pendidikan Indonesia: tidak diterbitkan.

Rokhmat, J., Marzuki, Hikmawati, \&Verawati, N. N. S. P. 2017a. Instrument Development of Causalitic Thinking Approach in Physics Learning to Increase Problem Solving Ability of Pre-service Teacher. American Institute of Physics Conference Proceeding of the 6th International Conference on Theoretical and Applied Physics (ICTAP) 2016, pp, 03000-3 - 03000-5.

2017b. The Causal Model in Physics Learning with a Causaliticthinking Approach to Increase the Problem-solving Ability of Pre- 
service Teachers. Pertanika Journal of Social Science and Humanities (JSSH), 25(S), 164.

(2017c). The Scaffolding Causalitic-thinking Approach to Increase the Problemsolving Ability of Students on Fluids. Proceeding of Science, Engineering, Education, and Developments Studies (SEEDs) Conference Series, 1(1), 52.

Rokhmat, J., Marzuki, Wahyudi, \& Putrie, S. D. 2019. A Strategy of Scaffolding Development to Increase Students' Problem-Solving Abilities: The Case of Physics Learning with CausaliticThinking Approach. Journal of Turkish Science Education (JTSE), 16(4), 570.

Rokhmat, J., Marzuki, Hikmawati, \& Verawati, N. N. S. P. 2020. The Causal Model in Physics Learning with a Causaliticthinking Approach to Increase the Problem-solving Ability of Pre-service Teachers. Pertanika Journals Social Sciences \& Humanities, 25(S), 155.

Setiawan, R. H., \& Harta, I. 2014. Pengaruh Pendekatan Open-Ended dan Pendekatan Kontekstual terhadap Kemampuan Pemecahan Masalah dan Sikap Siswa terhadap Matematika. Junral Riset Pendidikan Matematika, 1(2), 248-249.

Setyosari, P. 2016. Metode Penelitian dan Pengembangan (Edisi Keempat). Jakarta: Kencana.

Siregar, N. 2019. Upaya Meningkatkan Kemampuan Penalaran dan Komunikasi Matematis Siswa Melalui Model Pace. Jurnal Pedagogy, 4(2), 69.

Suminiangsih, 2020. Aplikasi Zoom Cloud Meetings Maksimalkan Belajar di Rumah. https://poskita.co/2020/03/24/aplikasi -zoom-cloud-meetings-maksimalkanbelajar-di-rumah/, Diakses tanggal 1 Mei 2020.
Sundayana, R. 2016. Statistik Penelitian Pendidikan. Bandung: Alfabeta.

Supeno, Kurnianingrum, A. M., \& Cahyani, M. U., 2017. Kemampuan Penalaran Berbasis Bukti Dalam Pembelajaran Fisika. Jurnal Pembelajaran dan Pendidikan Sains, 2 (1), 65.

Tamami, F., Rokhmat, J., \& Gunada, I. W. 2017. Pengaruh Pendekatan Berpikir Kausalitik Scaffolding Tipe 2a Modifikasi Berbantuan LKS Terhadap Kemampuan Pemecahan Masalah Optik Geometri Dan Kreativitas Siswa Kelas XI SMAN 1 Mataram. Jurnal Pendidikan Fisika dan Teknologi, 3(1), 76-83.

Wulandari, T. (2019). Pengaruh Model Pembelajaran Kausalitik terhadap Kemampuan Pemecahan Masalah dan Berpikir Kreatif Peserta Didik pada Materi Momentum dan Impuls. Skripsi S1. Universitas Mataram. 